\title{
Taxonomic note of Parnassia (Celastraceae) in China: a reassessment of Subsect. Xiphosandra
}

\author{
Huiying Yu', Feiyi Guo', Yumin Shu², Zhixiang Zhang',3 \\ I Laboratory of Systematic Evolution and Biogeography of Woody Plants, College of Nature Conservation, Bei- \\ jing Forestry University, Beijing 100083, China 2 Institute of Plant Adaptation and Utilization in Southwest \\ Mountain, College of Life Science, China West Normal University, Nanchong, Sichuan 637002, China 3 Mu- \\ seum of Beijing Forestry University, Beijing 100083, China
}

Corresponding author:Zhixiang Zhang (zxzhang@bjfu.edu.cn)

Academic editor:M.P.Simmons | Received 15October 2018| Accepted26 November 2018 | Published 20 December 2018

Citation: Yu H, Guo F, Shu Y, Zhang Z (2018) Taxonomic note of Parnassia (Celastraceae) in China: a reassessment of Subsect. Xiphosandra. PhytoKeys 114: 43-54. https://doi.org/10.3897/phytokeys.114.30551

\begin{abstract}
P. brevistyla, P. delavayi and P. leptophylla. belong to Celastraceae, Parnassia L., Sect. Nectarotrilobos Drude, Subsect. Xiphosandra (Franch.) Ku. Due to lack of material, the reliability of their taxonomic characteristics remained unknown and all three species have been retained. Following extensive field investigations, population sampling and examination of specimens, we determined that the previously used characteristics to distinguish these three species, i.e. the shape of basal leaves and the depth of staminode lobes, vary continuously within populations and should not be used to distinguish separate species. Therefore, $P$. brevistyla and $P$. leptophylla are hereby designated as synonyms of $P$. delavayi.
\end{abstract}

\section{Keywords}

Subsect. Xiphosandra, Celastraceae, new synonym, taxonomy

\section{Introduction}

Parnassia L. (Linnaeus 1753) is a genus that is predominantly distributed in the arctic and temperate zones of the Northern Hemisphere; it is most speciose in China and the Himalayas (Simmons 2004). All species of Parnassia are perennial herbs, glabrous; 
flowers solitary, borne on unbranched scape, actinomorphic, hermaphrodite; staminodes 5, inserted opposite to petals, terete and entire or flat and divided into lobes or filiform rays. The genus was traditionally placed in the family Saxifragaceae (Hooker and Thompson 1858, Engler 1930, Cronquist 1981, Ku 1995, Ku and Hultgård 2001); however, it was recently transferred to Celastraceae (APG IV 2016, Ball 2016) based on molecular evidence (Soltis et al. 1997, Soltis et al. 2000, Zhang and Simmons 2006, APG IV 2016). The latest updated checklist of the genus recognised 61 species, 2 subspecies, 11 varieties and 1 forma (Shu et al. 2017).

Subsect. Xiphosandra (Franch.) Ku (1987) has been recognised as consisting of those species in which the stamen connectives apically project as lanceolate appendages (Fig. 1g). It includes three species: P. brevistyla, P. delavayi and P. leptophylla. Based on unique morphological characteristics (i.e. the stamen connectives apically project as lanceolate appendages), the three species were placed in Sect. Xiphosandra Franch. (Franchet 1897) with the support of Wu et al. (2003). Alternatively, most researchers placed them into Subsect. Xiphosandra of Sect. Nectarotrilobos Drude (Ku 1987, Wu 2005) or directly into Sect. Nectarotrilobos due to their flat and 3-lobed staminodes (Nekrassova 1927, Engler 1930, Handel-Mazzetti 1941).

Parnassia delavayi Franch. was published based on three collections (Delavay 217, Delavay s.n. and Delavay Parnassia n. 2) (Franchet 1896). Then, Parnassia delavayi Franch. var. brevistyla Brieger was proposed in 1922 based on specimens collected from Tibet, China, $3750 \mathrm{~m}$ and Schenhsi, China, $2600 \mathrm{~m}$, s.n. (Brieger 1922). HandelMazzetti (1931) promoted Parnassia delavayi var. brevistyla into the new species Parnassia brevistyla (Brieg.) Hand.-Mazz. Handel-Mazzetti (1941) published 10 new taxa, including Parnassia leptophylla Hand.-Mazz., on the basis of a specimen collected from Baoxing, Sichuan, China-KL Chu 3231. Since the authors did not specify the holotype of Parnassia delavayi or P. leptophylla in their publications, P00709352 (Fig. 2) was designated as the lectotype of $P$. delavayi and PE00866146 (Fig. 3) was designated as the lectotype of P. leptophylla by Shu et al. (2017). However, according to the information provided by the original description of $P$. brevistyla, these types of $P$. brevistyla were not found after reviewing the specimens and high-resolution images of specimens in major herbaria, which was also mentioned by Stafleu and Mennega (1995).

Based on the descriptions of $P$. brevistyla, $P$. delavayi and P. leptophylla, the differences amongst them mainly consist of two characteristics: the shape of leaf blades and the depth of staminode lobes (Ku 1995, Table 1). With regard to the shape of blades: P. brevistyla has ovate-cordate basal leaves, while the other two species have reniform

Table I. Morphological characters of the specimens amongst Parnassia brevistyla, P. delavayi and P. leptophylla.

\begin{tabular}{|c|c|c|c|}
\hline & P. brevistyla & P. delavayi & P. leptophylla \\
\hline Leaves & Ovate-cordate & $\begin{array}{c}\text { Reniform, occasionally } \\
\text { suborbicular }\end{array}$ & $\begin{array}{c}\text { Reniform, occasionally } \\
\text { suborbicular }\end{array}$ \\
\hline Staminodes & $\begin{array}{l}\text { Shallowly } 3 \text {-lobed,the length of } \\
\text { lobes is } 1 / 6 \text { or less of their length }\end{array}$ & $\begin{array}{l}\text { Shallowly 3-lobed or to half their } \\
\text { length }\end{array}$ & 3-lobed for ca. 3/4 of their length \\
\hline
\end{tabular}




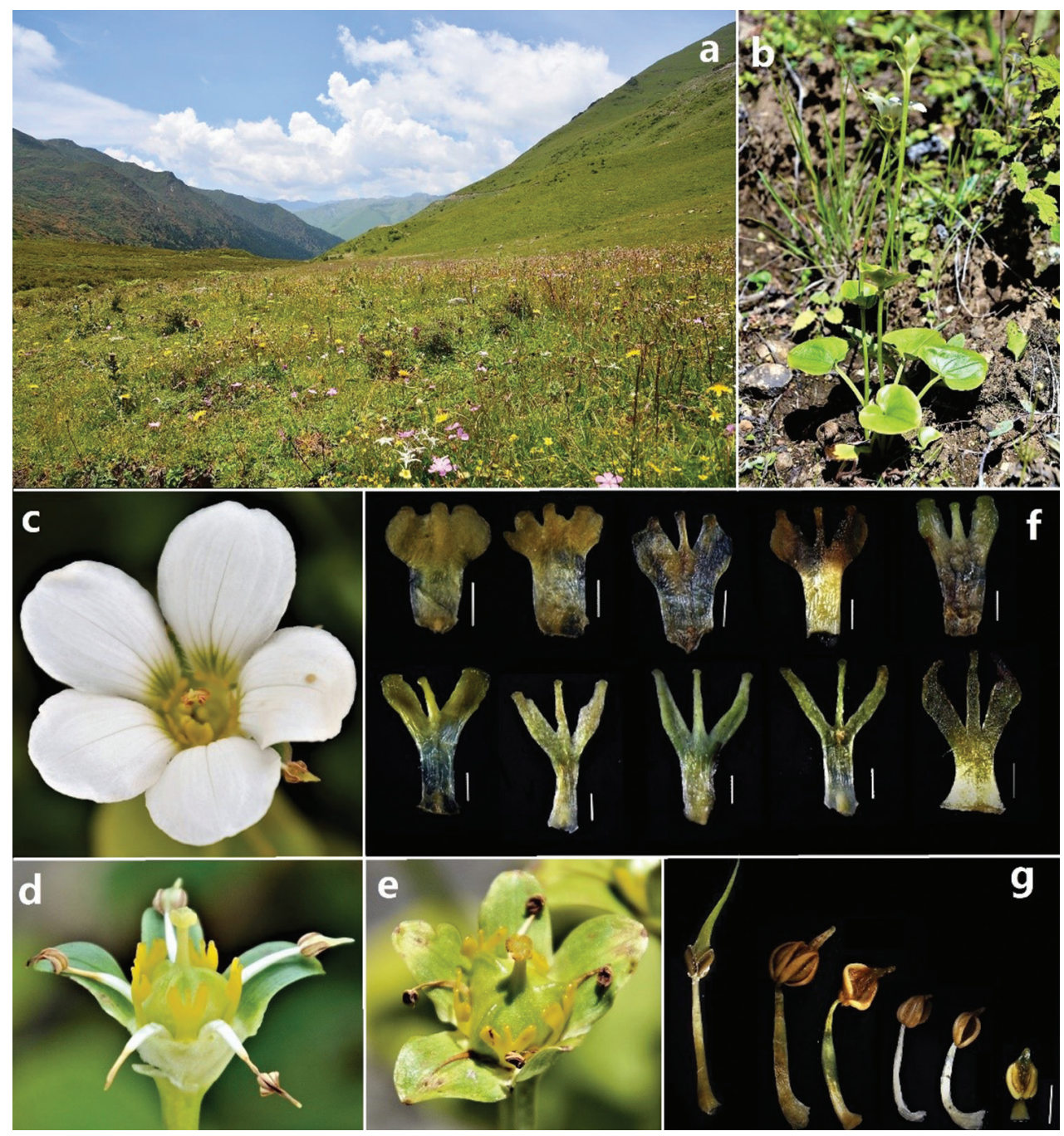

Figure I. Parnassia delavayi: habitat (a), individual (b), flower (c), fruits (d, e), staminodes (f) and stamens $(\mathbf{g})$. Scale bar: $1 \mathrm{~mm}$.

or occasionally suborbicular basal leaves. With regard to the depth of staminode lobes: P. brevistyla staminodes are shallowly 3-lobed and the length of lobes is $1 / 6$ or less of staminodes' length; $P$. delavayi staminodes are shallowly 3-lobed or to half their length; P. leptophylla staminodes are 3-lobed for ca. 3/4 of their length.

Through observation of herbarium specimens, we found that the three species of Subsect. Xiphosandra are extremely similar in morphology and there is obvious overlap amongst $P$. brevistyla, $P$. delavayi and $P$. leptophylla in the shape of leaf blades and the depth of staminode lobes. Moreover, during extensive field work, we found that the shape of basal leaves and the depth of staminode lobes varied significantly within pop- 


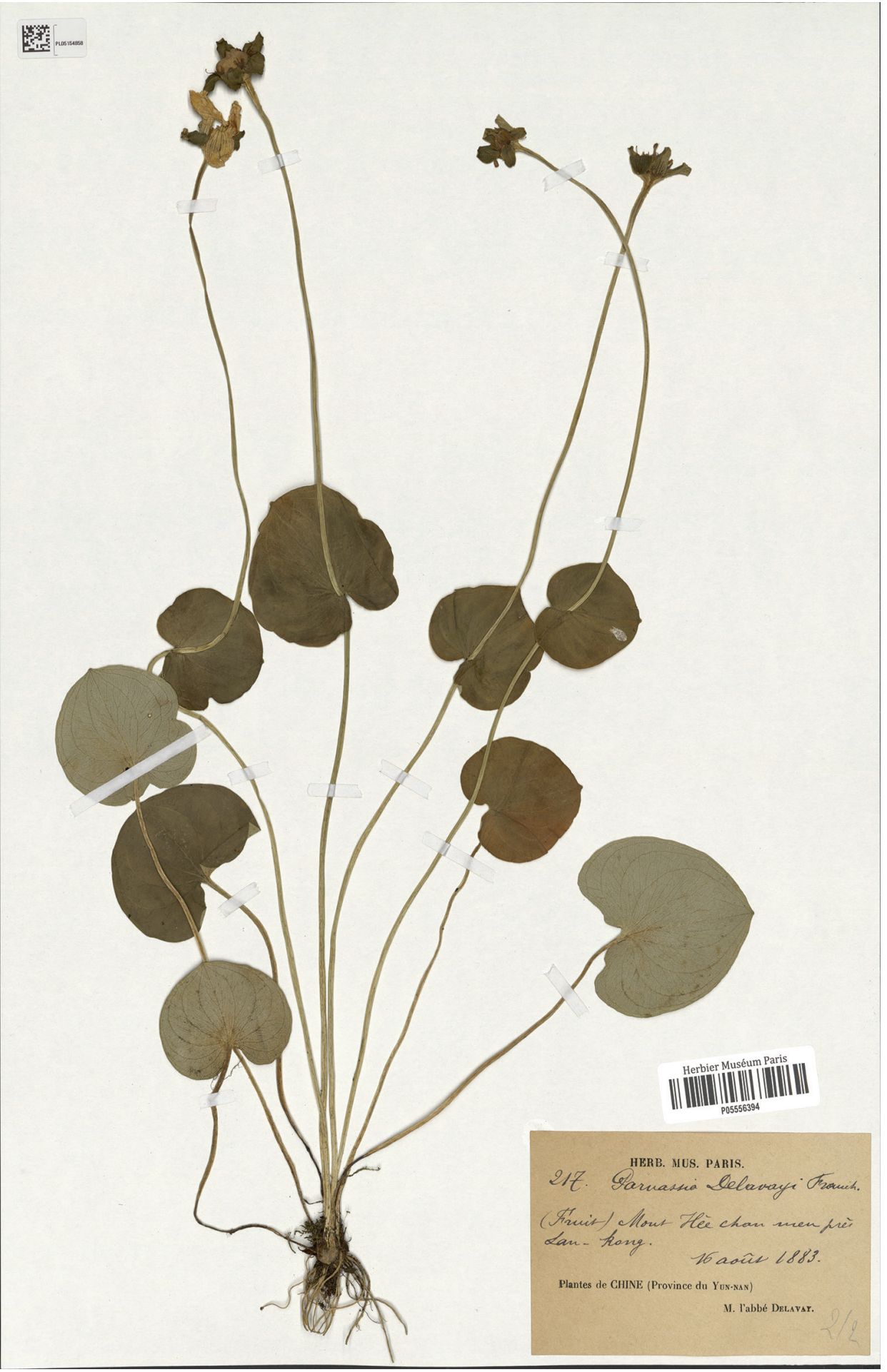

Figure 2. Parnassia delavayi, lectotype (P05556394). 


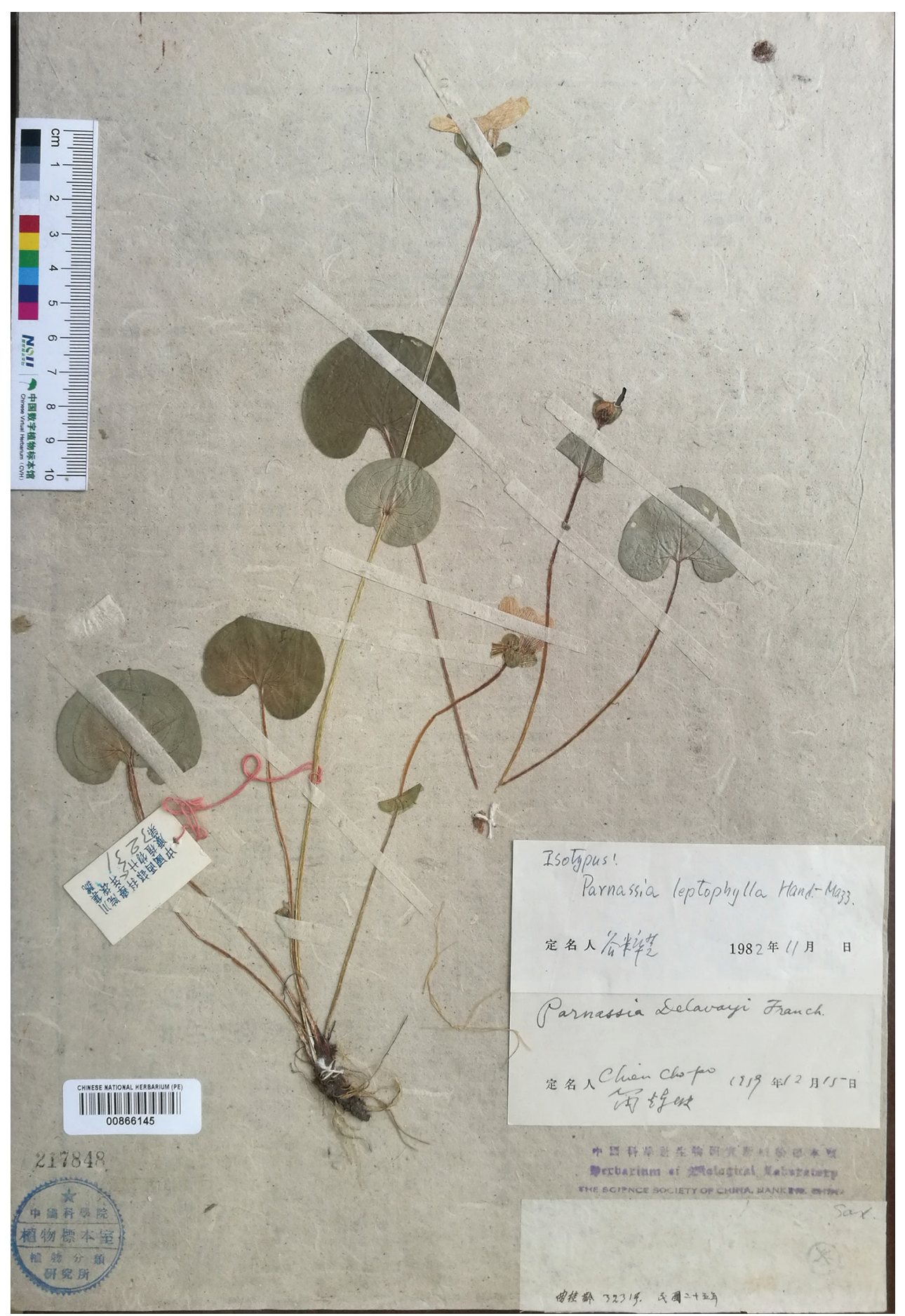

Figure 3. Parnassia leptophylla, lectotype (PE00866146). 
ulations, even sometimes within individuals. Therefore, the aim of this study was to clarify the classification relationship amongst $P$. brevistyla, $P$. delavayi and $P$. leptophylla by re-evaluating their morphological characteristics, particularly the shape of blades and the depth of staminode lobes.

\section{Material and methods}

Specimens from BJFC, CDBI, IMC, KUN, QFNU, P, PE, SM, SZ and WCNU (Suppl. material 1) were examined during this study. High-resolution photographs were also captured. The measurements provided herein were mostly obtained from dried herbarium specimens. Since the shape of both the leaf base and the apex are basically identical, the leaf shape is defined by the aspect ratio of leaves in this study. The primary examined populations were in Chongqing, Gansu, Guizhou, Hebei, Henan, Hubei, Hunan, Shanxi, Sichuan, Tibet and Yunnan. These populations include the type localities of $P$. brevistyla, $P$. delavayi and $P$. leptophylla (Taibai, Shanxi; Baoxing, Sichuan; Heqing, Dali). To ensure the data are fully comprehensive, we have recorded all measurable traits, such as sepals and petals, in each population.

An Olympus SZX16 dissecting microscope was used for observations and an Olympus DP72 cooled digital colour camera was used to photograph leaves and staminodes. TpsDig software: Version 2.17 (http://life.bio.sunysb.edu/ee/rohlf/software. html) was used to measure the lengths and widths of leaves, thus improving the accuracy of experimental results.

Overlapping or non-overlapping standard deviations can be used to determine if there is continuous or discontinuous variation of a quantitative trait between two or more groups, thus providing evidence for species differentiation or merging. This approach was applied to the aspect ratio of leaves (the width of leaves / the length of leaves) and the depth of staminode lobes (the length of central lobes / the length of staminodes) (Fig. 4). A total of 100 populations from 11 provinces were studied. To ensure the universality and comprehensive nature of the data, we measured all available individuals.
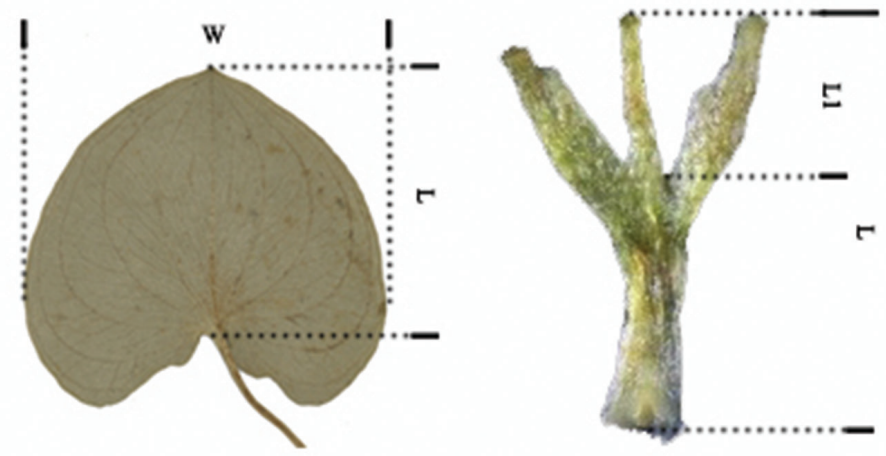

Figure 4. Measurements of leaves and staminodes: W: the width of leaves; L: the length of leaves / staminodes; L1: the length of central lobes. 

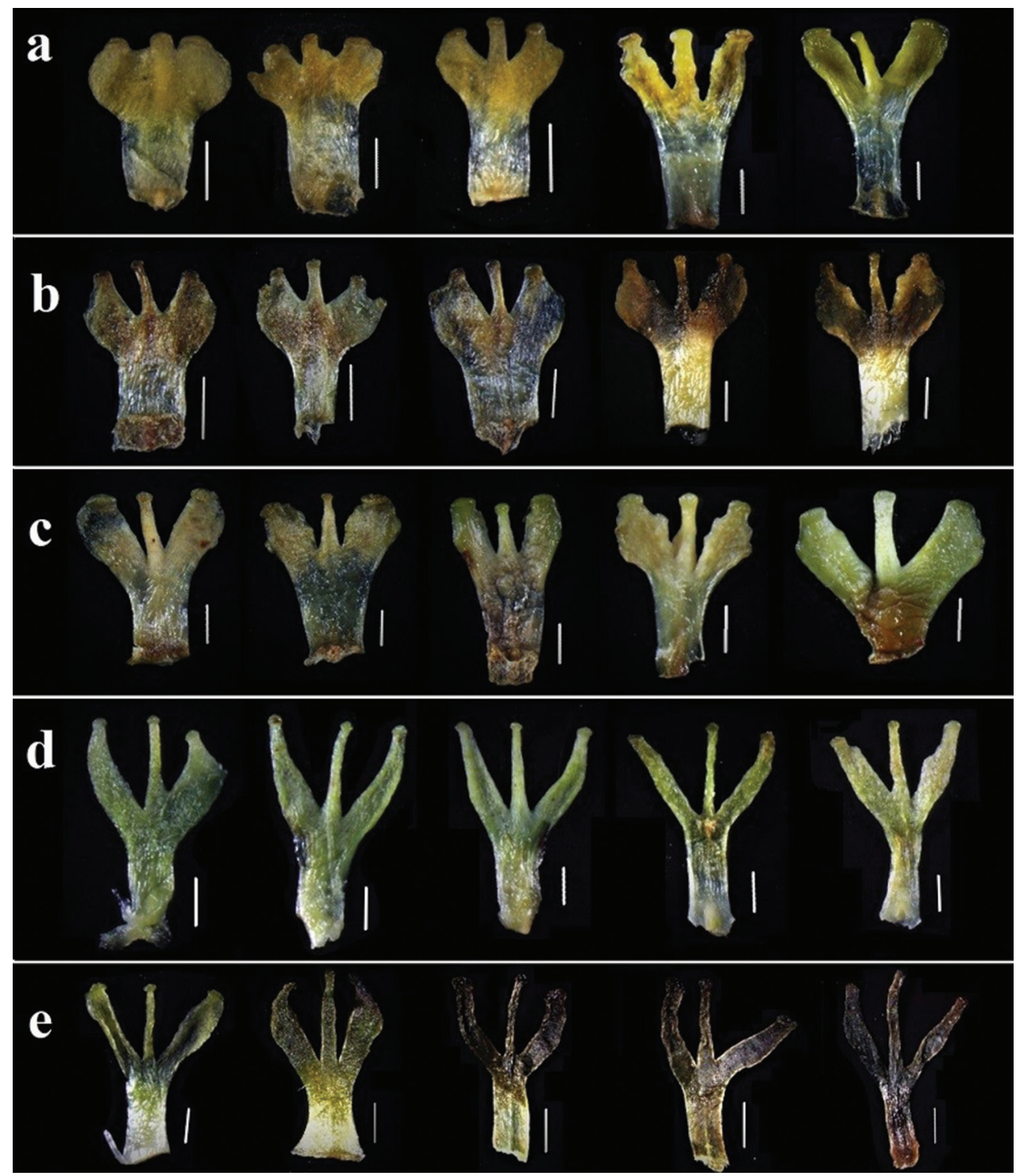

Figure 5. Variation of staminodes: $\mathbf{a}, \mathbf{b}$ represent variation of the depth of staminode lobes in population of Kangding, Sichuan c represents variation of the depth of staminode lobes in population of Baoxing, Sichuan (the type locality of Parnassia leptophylla) $\mathbf{d}$ represents variation of the depth of staminode lobes in population of Cangshan, Dali (the type locality of $P$. delavayi) e represents variation of the depth of staminode lobes in population of Mabian, Sichuan. Scale bar: $1 \mathrm{~mm}$.

\section{Results}

The morphological observations showed that the depth of staminode lobes varies considerably in the sampled populations, ranging from shallowly 3-lobed to 3-lobed for ca. 2/3 of their length (Fig. 5). Furthermore, the standard deviation analysis of the depth of staminode lobes also showed statistical continuity amongst populations of 


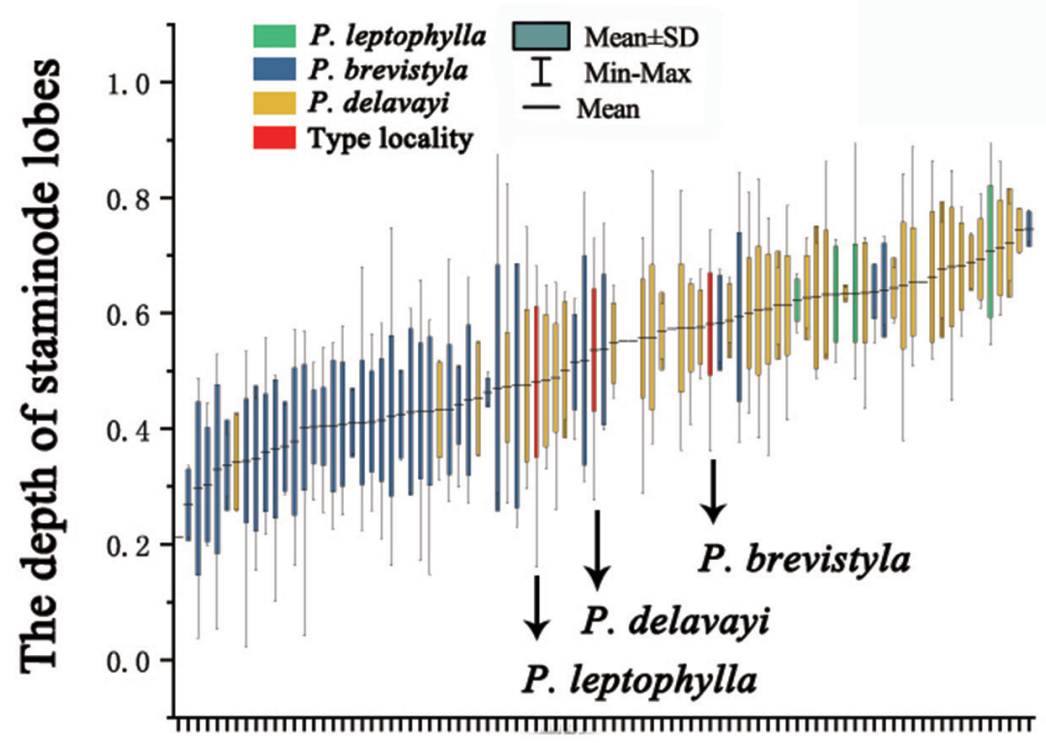

Figure 6. The standard deviation analysis of the depth of staminode lobes.

P. brevistyla, $P$. delavayi and $P$. leptophylla. As shown in Fig. 6, the variation of the depth of staminodes in the specimens collected from Baoji County, Heqing County and Baoxing County, where the types of $P$. brevistyla, $P$. delavayi and $P$. leptophylla were collected, is within the variation range of the population of $P$. brevistyla. There is also significant overlap of the depth of staminode lobes amongst the three species. Thus, $P$. brevistyla, $P$. delavayi and $P$. leptophylla show no differences in the depth of staminode lobes.

The shape of basal leaves has also been considered to be a distinguishing characteristic in previous treatments (Ku 1987, 1995). However, we found that the shape of basal leaves varies greatly within populations. Based on field experience, we found that their leaf shape varies dramatically, not only amongst different regions, but also in the same population. Shapes range from reniform, broadly cordate, to cordate and ovatecordate. As shown in Fig. 7, the variation of the blade aspect ratio in the specimens collected from type localities of $P$. brevistyla, $P$. delavayi and $P$. leptophylla is within the variation range of $P$. brevistyla populations. Furthermore, a significant overlap was found for the blade aspect ratio amongst these three species with respect to the observed ranges as well as the standard deviations (Fig. 7). Based on this continuous variation, it is difficult to find a dividing line to distinguish different leaf shapes.

In summary, $P$. brevistyla, $P$. delavayi and $P$. leptophylla show no differences in the shape of blades and the depth of staminode lobes. Thus, we treated $P$. brevistyla and $P$. leptophylla as new synonyms of $P$. delavayi. 


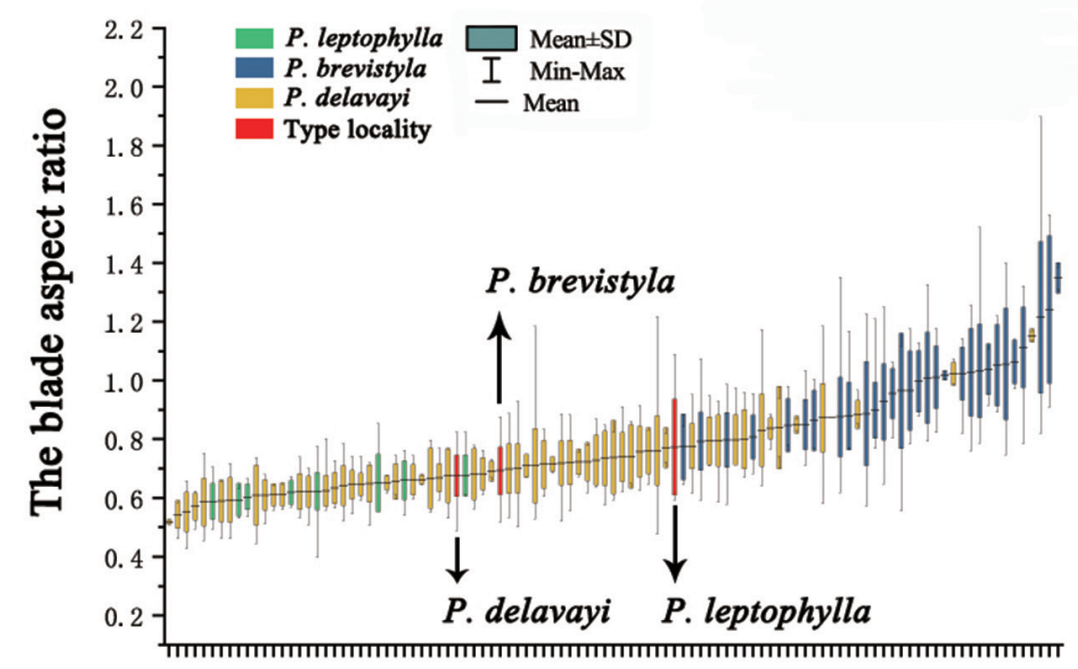

Figure 7. The standard deviation analysis of the blade aspect ratio.

\section{Discussion}

Hong (2016) proposed a new operational species concept called the morphologicalbiological species concept which emphasises that two or more qualitative traits or statistically discontinuous quantitative characters should exist between two species (Liu 2016). We applied this species concept in this study.

Taxonomically delimited species can be regarded as an assemblage of populations or individuals that have common morphological features and show distinct morphological discontinuity with other such assemblages in a number of characteristics (Singh 2004). That is, individuals of a given species show continuous variation in some characteristics. However, due to limitations of herbarium material, researchers can only observe a certain state of an individual within a population, rather than its variation within populations. Therefore, field investigation and random sampling within populations are important components of taxonomic studies (Xu et al. 2017). In this study, through both random sampling and statistical analysis within populations, the variability of morphological characteristics used in previous taxonomic treatments were analysed and reconsidered to avoid taxonomic artifacts that may be caused by undersampling.

We determined that both major characteristics that were previously used to distinguish $P$. brevistyla, $P$. delavayi and $P$. leptophylla, i.e. the shape of blades and the depth of staminode lobes, vary remarkably and continuously. Therefore, these characteristics should not be used to justify the recognition of three species. Furthermore, based on our examination of herbarium specimens as well as field observations, we found no other distinct characteristics to separate P. brevistyla, P. delavayi and $P$. leptophylla at the species level. 
Furthermore, the distributions of these three species are continuous and overlap. Therefore, since these three species lack clear morphologic distinction and overlap in their distribution range, we hereby reduce $P$. brevistyla and $P$. leptophylla to synonyms of $P$. delavayi.

\section{Taxonomic treatment}

\section{Parnassia delavayi Franchet, 1896: 267}

Fig. 2

=Parnassia brevistyla (Brieg.) Hand.-Mazz., 1931: 434. Syn. nov.

EParnassia delavayi Franch. var. brevistyla Brieger, 1922: 400. Syn. nov. Type: China. Tibet, 'Beju-Batang, Nadelwalder bei Chieda am Anstieg zum Passe Mala', $3500 \mathrm{~m}$ alt. (syntypes: not located); China. Schenhsi, Qingling, Taibaishan, Tempels Wanschuen-gou, $2600 \mathrm{~m}$ alt., s.n. 2720 (syntypes: not located).

=Parnassia leptophylla Hand.-Mazz., 1941: 120. Syn. nov. (Fig. 3) Type: China. Sichuan, Baoxing, KL Chu 3231 (lectotype designated by Shu et al. 2017: PE00866146!; isolectotypes: IBSC0145403!, PE00865960!, SZ00179815!). Fig. 3.

Type. CHINA. Yunnan, Eryuan (Lan-kong), Hee Chanmen, 2800 m alt., $16 \mathrm{Au}-$ gust 1883, Delavay 217 (lectotype designated by Shu et al. 2017: P05556394!; isolectotypes: P00709355!, P00709356!, P05556395!, P06392624!); CHINA. Yunnan, Eryuan, Lanho, Yanginchan, 7 August 1883, Delavay 130 (syntypes: P00709357!, P00709358!, P06392623!)

Description. Stems $1-5,10-40 \mathrm{~cm}$, with 1 cauline leaf proximally or near middle. Basal leaves 3-7(10); petiole 2-16 cm; blade reniform, cordate or ovate-cordate, $1-4 \times 1-4.5 \mathrm{~cm}$, base deeply cordate to subcordate, apex rounded, apiculate. Flower 2-4.5 cm in diam.; hypanthium turbinate or campanulate. Sepals oblong, ovate to obovate, 4-13 $\times 2-8 \mathrm{~mm}$, margin entire, apex rounded-obtuse. Petals white, sometimes green at base, obovate or oblong-obovate, $8-25 \times 5-12 \mathrm{~mm}$, base attenuate, margin erose in proximal 1/3, apex rounded or acute. Anthers ellipsoid, connective projected at apex into a lanceolate appendage, to $5 \mathrm{~mm}$; filaments ca. $5.5 \mathrm{~mm}$; staminodes 3-6 mm, shallowly 3-lobed or to half their length, rarely lateral ones 2-lobulate, lateral lobes usually wider than central one. Ovary superior, subglobose; stigma 3-lobed. Capsule obovoid with 3 thickened, longitudinal angles. Seeds brown, glossy, oblong. $2 \mathrm{n}=14$.

\section{Acknowledgements}

We are grateful to Ce Shang, Biao Xiong and Lei Wang for their valuable comments on the manuscript. We thank the curators of BJFC, CDBI, IMC, KUN, QFNU, P, $\mathrm{PE}, \mathrm{SM}, \mathrm{SZ}$ and WCNU for allowing us to examine specimens or use their images of 
specimens. This work was supported by the National Natural Science Foundation of China (grant no. 31110103911 \& J1310002) and the Science \& Technology Basic Work (grant no. 2017FY100100).

\section{References}

APG IV (2016) An update of the Angiosperm Phylogeny Group classification for the orders and families of flowering plants: APG IV. Botanical Journal of the Linnean Society 181(1): 1-20. https://doi.org/10.1111/boj.12385

Ball PW (2016) Parnassia. In: Ma JS, Ball PW, Levin GA (Eds) Flora of North America, vol. 12. Oxford University Press, New York \& Oxford, 113-117.

Brieger FG (1922) Aufzählung der von Dr. Limprichet in Ostasien gesammelten Pflanzen. Repertorium Specierum Novarum Regni Vegetabilis. Beihefte 12: 400-402. https://biodiversitylibrary.org/page/33525913

Cronquist A (1981) The integrated system of classification of flowering plants. Columbia University Press, New York, 1-1262.

Engler A (1930) Saxifragaceae. In: Engler A, Prantl K (Eds) Die Natürlichen Pflanzenfamillien 18a. W Englmann, Leipzig, 178-182.

Franchet AR (1896) Saxifragaceae, Crassulaceae, et Combretaceae novae. Journal de Botanique (Morot) 10(16): 260-282. https://biodiversitylibrary.org/page/8855851

Franchet AR (1897) Synopsis Parnassiarum florae Asiae orientalis. Bulletin de la Société Botanique de France 44: 244-263. http://www.biodiversitylibrary.org/item/8666. https://doi. org/10.1080/00378941.1897.10830772

Handel-Mazzetti H (1931) Saxifragacea, Parnassia. Symbolae Sinicae 7(2): 432-435. https:// doi.org/10.5962/bhl.title.878

Handel-Mazzetti H (1941) Kleine Beitrage zur Kenntnis der Flora von China. Oesterreichische Botanische Zeitschrift 90(2): 118-126. https://doi.org/10.1007/BF01257742

Hong DY (2016) Biodiversity pursuits need a scientific and operative species concept. Shengwu Duoyangxing 24(9): 979-999. https://doi.org/10.17520/biods.2016203

Hooker JD, Thompson T (1858) Præcursores ad floram Indicam. Journal of the Proceedings of the Linnean Society. Botany 2: 54-103. http://biodiversitylibrary.org/page/167541

Ku TC (1987) A revison of the genus Parnassia (Saxifragaceae) in China. Bulletin of Botanical Research 7(1): 1-57.

Ku TC (1995) Parnassia. In: Lu LT, Huang SM (Eds) Flora Reipublicae Popularis Sinicae, vol. 35. Science Press, Beijing, 1-66.

Ku TC, Hultgård UM (2001) Parnassia. In: Wu ZY, Raven PH (Eds) Flora of China, vol. 8. Missouri Botanical Garden Press, St. Louis and Science Press, Beijing, 95-118.

Linnaeus C (1753) Species plantarum, vol. 1. Laurentius Salvius, Stockholm, 560.

Liu BB (2016) A taxanomic revision of Pourthiaea Decne. (Rosaceae). PhD Thesis, University of China, Chinese Academy of Science.

Nekrassova V (1927) Les Parnassia de la section Nectarotrilobos. Bulletin de la Société Botanique de France 74(4): 635-655. https://doi.org/10.1080/00378941.1927.10833673 
Shu YM, Yu HY, Mu XY, Zhang ZX (2017) Checklist and typification of Parnassia (Celastraceae). Phytotaxa 309(1): 1-22. https://doi.org/10.11646/phytotaxa.309.1.1

Simmons MP (2004) Parnassiaceae. In: Kubitzki K (Ed.) The families and genera of vascular plants. Springer Verlag, Berlin, 291-296. https://doi.org/10.1007/978-3-662-07257-8_33

Singh G (2004) Hierarchical classification. In: Singh G (Ed.) Plant Systematics: An Integrated Approach. Science Publishers, Plymouth, 120-128.

Soltis DE, Soltis PS, Nickrent DL, Johnson LA, Hahn WJ, Hoot SB, Sweere JA, Kuzoff RK, Kron KA, Chase MW, Swensen SM, Zimmer EA, Chaw SM, Gillespie LJ, Kress WJ, Sytsma KJ (1997) Angiosperm phylogeny inferred from 18 S ribosomal DNA sequences. Annals of the Missouri Botanical Garden 84(1): 1-49. https://doi.org/10.2307/2399952

Soltis DE, Soltis PS, Chase MW, Mort ME, Albach DC, Zanis M, Saolainen V, Hahn WJ, Hoot SB, Fay MF, Axtell M, Swensen SM, Nixon KC, Farris JS (2000) Angiosperm phylogeny inferred from a combined data set of $18 \mathrm{~S} \mathrm{rDNA}, r b c \mathrm{~L}$, and $a t p \mathrm{~B}$ sequences. Botanical Journal of the Linnean Society 133(4): 381-461. https://doi.org/10.1111/j.1095-8339.2000.tb01588.x Stafleu FA, Mennega EA (1995) Taxonomic Literature: A Selective Guide to Botanical Publications and Collections with Dates, Commentaries and Types, supplement III: Br-Ca. Koeltz Scientific Books, Koenigstein, 73-74. https://doi.org/10.5962/bhl.title.48631

Wu D (2005) Phylogeny and Biogeography of the genus Parnassia. Kunming Istitute of Botany, Chinese Academy of Sciences.

Wu ZY, Lu AM, Tang YC, Chen ZD, Li DZ (2003) The families and genera of angiosperms in China a comprehensive analysis. Science Press, Beijing, 649-654.

Xu SJ, Shang C, Zhang ZX, Zhao LC (2017) The identity of Homalium breviracemosum (Salicaceae). Phytotaxa 326(1): 63-70. https://doi.org/10.11646/phytotaxa.326.1.5

Zhang LB, Simmons MP (2006) Phylogeny and delimitation of the Celastrales inferred from nuclear and plastid genes. Systematic Botany 31(1): 122-137. https://doi. org/10.1600/036364406775971778

\section{Supplementary material I}

\section{A list of herbarium specimens examined}

Authors: Huiying Yu, Feiyi Guo, Yumin Shu, Zhixiang Zhang

Data type: species data

Copyright notice: This dataset is made available under the Open Database License (http://opendatacommons.org/licenses/odbl/1.0/). The Open Database License $(\mathrm{ODbL})$ is a license agreement intended to allow users to freely share, modify, and use this Dataset while maintaining this same freedom for others, provided that the original source and author(s) are credited.

Link: https://doi.org/10.3897/phytokeys.114.30551.suppl1 